\title{
Pengaruh SSP Tematik terhadap Kejujuran dan Disiplin Peserta Didik Kelas I SD
}

\author{
M. Masnur \\ STKIP Muhammadiyah Enrekang. Jl. Jenderal Sudirman, Galonta, Kec. Enrekang, Kabupaten \\ Enrekang, Sulawesi Selatan 91711, Indonesia \\ Korespondensi Penulis. Email: masnur1985@gmail.com \\ Received: 6 January 2016; Revised:10 June 2016; Accepted: 3 October 2016
}

\begin{abstract}
Abstrak
Tujuan penelitian ini untuk mengetahui, pengaruh Subject Specific Pedagogy tematik terhadap peningkatan karakter kejujuran dan disiplin peserta didik pada tema peristiwa alam semester genap kelas I SDN tahun ajaran 2013/2014. Jenis Penelitian eksperimen semu dengan nonequivalent groups pretest-posttest design. Populasi penelitian ini adalah seluruh peserta didik kelas I SDN. Sampel dipilih dengan tekhnik purposive sampling. Teknik pengumpulan data yang digunakan adalah teknik angket dan teknik observasi. Teknik angket digunakan untuk mengetahui nilai karakter kejujuran dan disiplin peserta didik. Teknik observasi digunakan untuk mengungkap perilaku karakter kejujuran dan tingkah laku peserta didik. Teknik analisis data digunakan adalah Analisys of Variance dengan taraf signifikansi 0.05 . Hasil penelitian ini, secara signifkan berpengaruh positif terhadap peningkatan karakter kejujuran peserta didik diperoleh $\mathrm{p}<\alpha$ yaitu $\mathrm{p}=0,000<\alpha=0,05$ dengan $\mathrm{F}=27,890$; dan karakter disiplin peserta didik diperoleh $\mathrm{p}<\alpha$ yaitu $\mathrm{p}=0,000<\alpha=0,05$ dengan $\mathrm{F}=9,294$.
\end{abstract}

Kata Kunci: Subject Specific Pedagogy tematik, kejujuran, disiplin

\section{The Effect of SSP Thematic on Honesty and Discipline of Grade 1 Elementary School Students}

\begin{abstract}
The objective of this study was to determine the effect of Subject Specific Pedagogy thematic on students' honesty and discipline, for nature phenomenon theme of grade I of second semester in elementary school in the academic year of 2013/2014. This is a quasi experimental research with pretest and posttest nonequivalent control group design. The population comprised grade 1 elementary school students. The sample was established using purposive sampling technique. The data were collected through observation and questionnaire. The questionnaire was used to know the student's honesty and discipline value. The observation was used to know student of characters honesty and discipline behavior. The data were analyzed using variance test for the significance level of 0.05.The result of this study has significant positive effects on student's increase of honesty with $p<$ $\alpha$ that is $p=0,000<\alpha=0.05$ with $F=27.890$; and SSP thematic significantly has positive effects on students discipline with $p<\alpha$ that is $p=0,000<\alpha=0.05$ with $F=9.294$.
\end{abstract}

Keyword: SSP, thematic, honesty, discipline

How to Cite: Masnur, M. (2017). Pengaruh SSP tematik terhadap peningkatkan karakter kejujuran dan disiplin peserta didik kelas I SD.Jurnal Prima Edukasia, 5(1), 79-90. doi:http://dx.doi.org/10.21831/jpe.v5i1.7745

Permalink/DOI: http://dx.doi.org/10.21831/jpe.v5i1.7745 


\section{Pendahuluan}

Merosotnya moral di kalangan pemuda dan pemudi bangsa akhir-akhir ini telah banyak menyita perhatian berbagai kalangan, baik pemerintah maupun seluruh masyarakat Indonesia, hal ini menggambarkan adanya keprihatinan terhadap pengembangan nilai-nilai atau moral kehidupan karakter bangsa. Kondisi tersebut menunjukkan bahwa tidak ada dampak dari apa yang dipelajari peserta didik di sekolah untuk diwujudkan dalam kehidupan keseharian mereka. Krisis karakter ini tentu saja tidak sejalan dengan tujuan pendidikan nasional yang ditegaskan oleh Undang-Undang Pendidikan Nomor 20 Tahun 2003 tentang sistem Pendidikan Nasional pasal 3 yaitu "Pendidikan nasional berfungsi mengembangkan kemampuan dan membentuk peradaban bangsa yang bermartabat dalam rangka mencerdaskan bangsa bertujuan untuk berkembangnya potensi peserta didik agar menjadi manusia yang beriman dan bertaqwa kepada Tuhan Yang Maha Esa, berakhlak mulia, sehat, berilmu, cakap, kreatif, mandiri dan menjadi warga negara yang demokratis serta bertanggung jawab".

Pemerintah dalam hal ini sebagai pihak yang paling bertanggung jawab terhadap pendidikan anak bangsa sesuai dengan amanat Undang-Undang Dasar 1945 telah berusaha dan terus berusaha memperbaiki dunia pendidikan di Indonesia dengan terus membuat kebijakankebijakan yang bersifat positif terhadap dunia pendidikan nasional. Salah satu upaya yang secara nyata dilaksanakan pemerintah yaitu menyempurnakan Kurikulum Tingkat Satuan Pendidikan (KTSP) menjadi Kurikulum 2013 dengan mengintegrasikan pendidikan karakter didalamnya. Kemendikbud (2013, p.9) menjelaskan bahwa "pengintegrasian tersebut dilakukan dalam dua hal, yaitu integrasi sikap, keterampilan dan pengetahuan dalam proses pembelajaran dan integrasi berbagai konsep dasar yang berkaitan".

Pendidikan karakter merupakan langkah sangat penting dan strategis dalam membangun kembali jati diri bangsa dan karakter masyarakat Indonesia. Tidak bisa dipungkiri pendidikan karakter memang sangat urgen bagi bangsa Indonesia, terutama untuk mempersiapkan generasi muda sebagai para calon pemimpin bangsa di masa yang akan dating. Pendidikan karakter seharusnya membawa peserta didik ke pengenalan nilai secara kognitif, penghayatan nilai secara afektif, dan akhirnya ke pengamal- an nilai secara nyata. Lickona (1991, pp. 53-62) menekankan pentingnya tiga komponen karakter yang baik (component of good character) dalam mengembangkan pendidikan karakter yaitu: moral knowing atau pengetahuan tentang moral, moral feeling atau perasaan tentang moral, dan moral action atau perbuatan bermoral. Memadukan secara seimbang ketiga komponen tersebut, diharapkan peserta didik mampu menghayati dan memahami nilai-nilai luhur yang khas-baik (tahu nilai kebaikan, mau berbuat baik nyata berkehidupan baik, dan berdampak baik terhadap lingkungan. Sehingga pendidikan karakter senantiasa mengarahkan diri pada pembentukan individu bermoral, cakap mengambil keputusan yang tampil dalam perilakunya, sekaligus mampu berperan aktif dalam membangun kehidupan bersama dalam tantangan global.

Pembentukan karakter sangat baik dilakukan di usia SD dan terus berlanjut ke jenjang yang lebih tinggi. Pada usia kelas I SD apabila menurut pembagian fase diatas digolongkan dalam fase masa kelas rendah SD yang umurnya antara 7-11 tahun. Menurut Piaget (Berk, 2007, p.298) "Concrete operational stage, which extends from 7 to 11 years and marks a major turning point in cognitive development. Thought is far more logical, flexible, and organized than it was earlier". Pada tahap operasional konkrit yang merupakan masa-masa yang kritis, dan dapat juga dikatakan usia yang sangat baik untuk membentuk kemampuan berfikir anak sekolah dasar. Pada masa ini lebih mudah membentuk karakter anak, hal in karena peserta didik lebih cepat menyerap perilaku dari lingkungan sekitarnya dan perkembangan mental berlangsung sangat cepat, oleh karena itu lingkungan yang baik akan membentuk karakter yang positif.

Namun pada kenyataanya nampak belum optimalnya penanaman nilai karakter yang diharapkan dapat dimiliki oleh peserta didik. Hal ini disebabkan karena dalam proses pembelajaran hanya menekankan pada aspek kognitif saja dan mengabaikan aspek afektif dalam pembelajaran. Berkaitan dengan permasalahan yang ada, nilai karakter peserta didik semakin dipertanyakan. Permasalahan lain yang dihadapi guru adalah guru-guru mengalami kesulitan pada saat membuat rencana pelaksanaan pembelajaran (RPP), karena setiap hari rubrik dan tema-tema yang diberikan kepada peserta didik harus disiapkan, sedangkan contoh yang diberikan hanya sebagian. Walaupun guru-guru 
telah memperoleh pelatihan tentang gambaran pelaksanaan kurikulum 2013, namun masih dirasa kurang dalam mempersiapkan segala sesuatu terkait pembuatan perangkat pembelajaran. Oleh karena itu guru dituntut untuk lebih berkompeten dalam memfasilitasi peserta didik. Maka perlu adanya pengetahuan bagaimana menggabungkan antara isi (konten) dan pendidikan secara efektif agar mudah dipahami anak. Keterampilan mengemas antara pengetahuan teoretis mengenai konsep yang hendak diajarkan dengan pengetahuan mendidik agar nantinya dapat membentuk sikap peserta didik kearan yang lebih baik, salah satu bentuk inovasi yang ditawarkan adalah dengan menggunakan Subject Specific Pedagogy (SSP).

California State University Northridge (CSUN) (2006, p.5) menjelaskan bahwa "Subject specific pedagogy, also known as pedagogical content knowledge, is a form of teacher knowledge and a part of a teacher's thinking process". Oleh karena itu pengetahuan ini berusaha menjembatangi antara pencapaian pengetahuan mata pelajaran dengan perubahan lingkungan dalam pembelajaran, sehingga mengembangkan nilai karakter peserta didik secara bertahap. SSP tematik yang terintegrasi pendidikan karakter bertujuan untuk membangun seluruh dimensi manusia dengan pendekatan ilmiah (scientific approach) pada pengalaman belajar yang menyenangkan dan inspiratif untuk peserta didik.

Berdasarkan hasil observasi dan wawancara pada beberapa sekolah dasar di kecamatan ujung kota parepare, untuk pembelajaran tematik saat ini nilai afektif peserta didik belum memuaskan. Aspek kejujuran, perilaku disiplin, sikap objektif, berpikir kritis, dan peserta didik cenderung pasif. Berdasarkan latar belakang yang telah diuraikan, penulis berusaha melihat dan mengukur sampai menganalisis pengaruh SSP tematik tehadap peningkatan karakter kejujuran dan disiplin peserta didik kelas I SDN di Kecamatan Ujung Kota Parepare.

\section{Metode}

Penelitian ini menggunakan pendekatan kuantitatif dengan metode quasi-experimental atau eksperimen semu yang bertujuan untuk membandingkan dua perlakuan yang berbeda kepada subjek penelitian. Penelitian ini bertujuan mengetahui pengaruh SSP tematik terhadap karakter peserta didik.

Penelitian ini menggunakan desain nonequivalent groups pretest-posttest control group design. Menurut McMilan \& Schumacher (2010, p.278) mengemukakan bahwa "nonequivalent groups pretest-posttest control or comparison group designs are designs very prevalent and useful in education, because it is often impossible to randomly assign subject". Gambar visual desain penelitian ini adalah seperti tampak pada gambar 1.

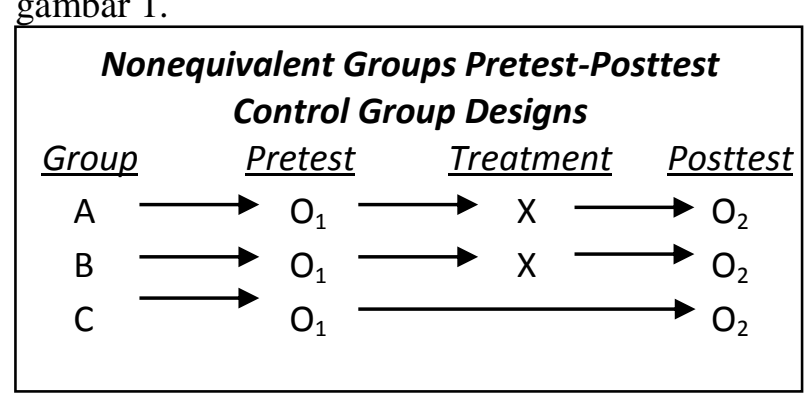

Gambar 1. Desain penelitian Nonequivalent Groups Pretest-Posttest Design

Keterangan:

$\mathrm{A}=$ Kelompok Eksperimen

$\mathrm{B}=$ Kelompok Eksperimen

$\mathrm{C}=$ Kelompok Kontrol

$\mathrm{O}_{1}=$ Pretest pada kelompok eksperimen dan kelompok kontrol

$\mathrm{O}_{2}=$ Posttest pada kelompok eksperimen dan kelompok kontrol

$\mathrm{X}=$ Perlakuan dengan menggunakan Subject Specific Pedagogy tematik.

Populasi pada penelitian ini adalah seluruh peserta didik kelas 1 di Kecamatan Ujung Kota Parepare Tahun Pelajaran 2013/2014. Sampel diambil dengan cara tekhnik purposive sampling. Pemilihan sampel penelitian ditentukan dengan berdasarkan pertimbangan-pertimbangan peneliti sesuai dengan tujuan atau maksud penelitian.

Teknik pengumpulan data yang digunakan adalah teknik angket dan observasi. Angket digunakan untuk mengetahui nilai karakter kejujuran dan disiplin peserta didik. Angket ini berisi 20 butir pernyataan, baik pernyataan positif maupun negatif. Untuk nilai kejujuran terdiri dari 10 butir pernyataan dan 10 butir untuk nilai disiplin dengan pilihan jawaban menggunakan skala rentang (rating-scale) dibuat dalam bentuk checklist dengan skor yang diberikan $1-4$. Teknik observasi digunakan untuk memperoleh informasi terkait nilai-nilai karakter yang tampak dari perilaku peserta didik selama proses belajar mengajar berlangsung. Instrumen ini terdiri 15 butir pernyataan yang terbagi ke dalam dua kategori nilai, yaitu 
kejujuran dan disiplin. Untuk nilai kejujuran terdiri dari 7 butir pernyataan dan 8 butir untuk nilai disiplin dengan pilihan jawaban menggunakan skala rentang dibuat dalam bentuk checklist dengan skor yang diberikan 1-4.

Teknik analisis data yang digunakan adalah Statistik deskriptif dan Statistik Inferensial. Statistik deskriptif digunakan untuk menyajikan data yang telah diperoleh melalui angket dan observasi dalam bentuk tabel. Untuk menentukan pengaruh SSP dapat dilihat dari dua aspek yaitu hasil pretest dan posttest melalui angket dan hasil observasi karakter peserta didik. Menurut Mardapi (2008, pp.122-123) skor yang diperoleh kemudian dikonversikan menjadi kriteria dengan acuan, batasan kategori nilai karakter peserta didik disusun sebagaimana pada Tabel 1.

Tabel 1. Kategorisasi Karakter Peserta Didik

\begin{tabular}{lcc}
\hline No & Skor Peserta Didik & Kriteria Kualitatif \\
\hline 1. & $X \geq \bar{X}+1 . \mathrm{SBx}$ & Sangat positif \\
2. & $\bar{X}+1 . \mathrm{SBx}>X \geq \bar{X}$ & Tinggi \\
3. & $\bar{X}>X \geq \bar{X}-1 . \mathrm{SBx}$ & Negatif \\
4. & $X<\bar{X}-1 . \mathrm{SBx}$ & Sangat negatif \\
\hline
\end{tabular}

\section{Keterangan:}

$\mathrm{X}=$ Skor aktual

$\bar{X} \quad=$ Rerata ideal $=1 / 2\left(X_{\max }+X_{\min }\right)$

$\mathrm{SBx}=$ Simpangan baku ideal $=1 / 6\left(\mathrm{X}_{\max }+\mathrm{X}_{\min }\right)$

Untuk menentukan pengaruh SSP dapat dilihat dari dua aspek yaitu hasil pretest dan posttest melalui angket dan hasil observasi karakter peserta didik. Mengacu pada kriteria penilaian ideal pada Tabel 1, maka batasan kategori nilai karakter peserta didik disusun sebagaimana pada Tabel 2 .

Tabel 2. Batasan Kategorisasi Karakter Peserta Didik

\begin{tabular}{|c|c|c|c|}
\hline \multicolumn{3}{|c|}{ Rentang skor (i) } & \multirow{3}{*}{ Kategori } \\
\hline \multicolumn{2}{|c|}{ Observasi } & Angket & \\
\hline Kejujuran & Disiplin & $\begin{array}{c}\text { Kejujuran/ } \\
\text { Disiplin }\end{array}$ & \\
\hline$X>21$ & $X>24$ & $X>30$ & $\begin{array}{l}\text { Sangat } \\
\text { positif }\end{array}$ \\
\hline $21>X \geq 17,5$ & $24>X \geq 20$ & $30>X \geq 25$ & Positif \\
\hline $17,5>X \geq 14$ & $20>X \geq 16$ & $25>X \geq 20$ & Negatif \\
\hline$x<14$ & $X<16$ & $X<20$ & $\begin{array}{l}\text { Sangat } \\
\text { negatif }\end{array}$ \\
\hline
\end{tabular}

Keterangan: $\mathrm{X}=$ total skor actual.

Statistik Inferensial dilakukan dalam upaya penarikan kesimpulan dan membuat keputusan berdasarkan data yang diperoleh dari angket dianalis dengan Analisys of variance (ANOVA). Kriteria penerimaan dan penolakan
$H_{o}$ pada taraf signifikansi 5\% atau 0.05 dengan menggunakan signifikansi, yaitu jika $\mathrm{p}>\alpha$ maka $H_{o}$ diterima dan sebaliknya $\mathrm{p}<\alpha$ maka $H_{o}$ ditolak. Namun, sebelumnya perlu diuji prasyarat analisis dengan uji normalitas dan homogenitas. Pengujian normalitas dengan kolmogrov-sminov dengan bantuan komputer menggunakan program SPSS 20.00 for windows. Kolmogorov-Smirnov. Selanjutnya dilakukan Uji homogenitas digunakan adalah levene'stest for equality variansces dengan bantuan computer dengan menggunakan program SPSS 20.00 for windows.

\section{Hasil dan Pembahasan}

Hasil penelitian dengan menggunakan SSP tematik yaitu berupa hasil angket penilaian karakter dan hasil observasi karakter peserta didik. Data penelitian ini meliputi data penilaian nilai karakter terdiri dari yaitu observasi karakter dan data pretest dan posttest yang diperoleh melalui angket. Secara singkat dapat dideskripsikan data nilai karakter yang mengungkapkan informasi mean (M), mode (Mo), median $(\mathrm{Md})$, standar deviation $(\mathrm{s})$, variance $\left(\mathrm{s}^{2}\right)$.

Hasil lembar observasi checklist karakter kejujuran peserta didik $\mathrm{KE}_{1}$ setiap minggunya disajikan pada Tabel 3.

Tabel 3. Hasil lembar Observasi checklist Karakter Kejujuran $\mathrm{KE}_{1}$

\begin{tabular}{ccccc}
\hline \multirow{2}{*}{ Keterangan } & \multicolumn{4}{c}{ Skor tiap minggu } \\
\cline { 2 - 5 } & I & II & III & IV \\
\hline$M$ & 14.62 & 16.62 & 19.29 & 22.86 \\
$M d$ & 14.00 & 16.00 & 19.00 & 23.00 \\
$M o$ & 14.00 & 16.00 & 20.00 & 23.00 \\
$S$ & 1.396 & 1.396 & 1.678 & 1.195 \\
$s^{2}$ & 1.948 & 1.948 & 2.814 & 1.429 \\
\hline
\end{tabular}

Berdasarkan pada Tabel 3, terdapat perbedaan skor yang diperoleh peserta didik $\mathrm{KE}_{1}$ setiap minggunya. Hal ini menunjukkan bahwa terdapat peningkatan karakter kejujuran peserta didik $\mathrm{KE}_{1}$ setelah penggunaan SSP. Data skor hasil observasi penilaian karakter kejujuran, kemudian dikelompokkan sesuai kategori nilai yang diperoleh peserta didik. Secara singkat dapat dideskripsikan data nilai karakter yang mengungkapkan informasi yaitu: Sangat positif $(\mathrm{Sp})$, Positif $(\mathrm{P})$, Negatif $(\mathrm{N})$, dan Sangat negatif (Sn). Untuk lebih jelasnya dapat dilihat pada Tabel 4. 
Tabel 4. Skor Hasil lembar Observasi checklist Karakter Kejujuran Peserta Didik $\mathrm{KE}_{1}$

\begin{tabular}{cccccc}
\hline \multirow{2}{*}{ Kategori } & \multirow{2}{*}{ Skor } & \multicolumn{4}{c}{ Observasi tiap minggu } \\
\cline { 3 - 6 } & & I & II & III & IV \\
\hline $\mathrm{Sp}$ & $\mathrm{X} \geq 21$ & - & - & 4 & 21 \\
$\mathrm{P}$ & $20>\mathrm{X} \geq 17,5$ & - & 5 & 13 & - \\
$\mathrm{N}$ & $17,5>\mathrm{X} \geq 14$ & 16 & 16 & 4 & - \\
$\mathrm{Sn}$ & $\mathrm{X}<14$ & 5 & - & - & - \\
Jumlah peserta didik & 21 & 21 & 21 & 21 \\
\hline
\end{tabular}

Data skor aktual yang diperoleh peserta didik setiap minggunya dikelompokkan sesuai kategori nilai yang diperoleh, dapat disajikan ke dalam histogram seperti pada Gambar 2.

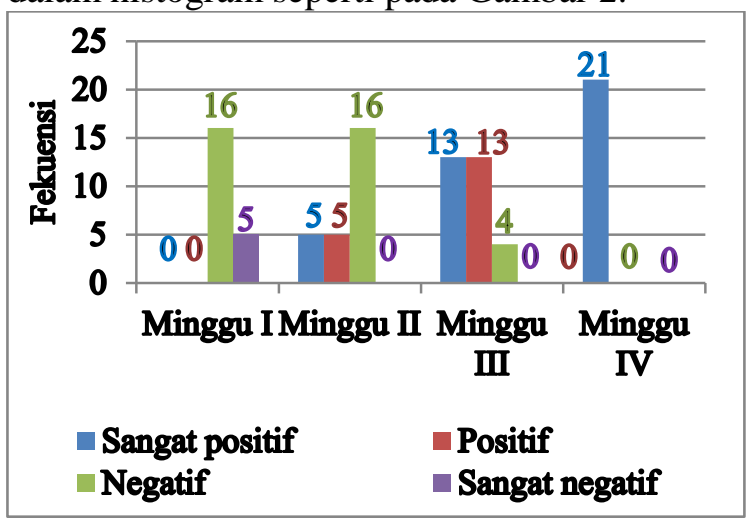

Gambar 2. Histogram Skor Hasil Observasi checklist Karakter Kejujuran Peserta Didik $\mathrm{KE}_{1}$

Berdasarkan Gambar 2, diketahui skor aktual yang diperoleh peserta didik berkategori nilai "sangat positif" terjadi peningkatan setiap minggunya, dapat disimpulkan bahwa penggunaan SSP tematik dapat meningkatkan karakter kejujuran peserta didik.

Hasil lembar observasi checklist karakter disiplin peserta didik $\mathrm{KE}_{1}$ setiap minggunya disajikan pada Tabel 5.

Tabel 5. Hasil lembar Observasi checklist Karakter Disiplin $\mathrm{KE}_{1}$

\begin{tabular}{ccccc}
\hline \multirow{2}{*}{ Keterangan } & \multicolumn{4}{c}{ Skor tiap minggu } \\
\cline { 2 - 5 } & I & II & III & IV \\
\hline$M$ & 18.67 & 21.67 & 24.23 & 27.09 \\
$M d$ & 18.00 & 21.00 & 24.00 & 27.00 \\
$M o$ & 18.00 & 21.00 & 25.00 & 27.00 \\
$s$ & 1.683 & 1.683 & 1.300 & 1.220 \\
$s^{2}$ & 2.833 & 2.833 & 1.690 & 1.490 \\
\hline
\end{tabular}

Berdasarkan pada Tabel 5, terdapat perbedaan skor yang diperoleh peserta didik $\mathrm{KE}_{1}$ setiap minggunya. Hal ini menunjukkan bahwa terdapat peningkatan karakter disiplin peserta didik $\mathrm{KE}_{1}$ setelah penggunaan SSP. Data skor hasil observasi penilaian karakter disiplin, kemudian dikelompokkan sesuai dengan kategori nilai yang diperoleh peserta didik. Untuk lebih jelasnya dapat dilihat pada Tabel 6 .

Tabel 6. Skor Hasil lembar Observasi checklist Karakter Disiplin Peserta Didik $\mathrm{KE}_{1}$

\begin{tabular}{cccccc}
\hline \multirow{2}{*}{ Kategori } & \multirow{2}{*}{ Skor } & \multicolumn{5}{c}{ Observasi tiap minggu } \\
\cline { 3 - 6 } & & I & II & III & IV \\
\hline Sp & $\mathrm{X} \geq 24$ & - & 4 & 14 & 21 \\
$\mathrm{P}$ & $24>\mathrm{X} \geq 20$ & 8 & 15 & 7 & - \\
$\mathrm{N}$ & $20>\mathrm{X} \geq 16$ & 13 & 2 & - & - \\
$\mathrm{Sn}$ & $\mathrm{X}<16$ & - & - & - & - \\
Jumlah peserta didik & 21 & 21 & 21 & 21 \\
\hline
\end{tabular}

Data skor aktual yang diperoleh peserta didik setiap minggunya dikelompokkan sesuai kategori nilai yang diperoleh, untuk lebih jelasnya dapat disajikan kedalam histogram seperti pada Gambar 3.

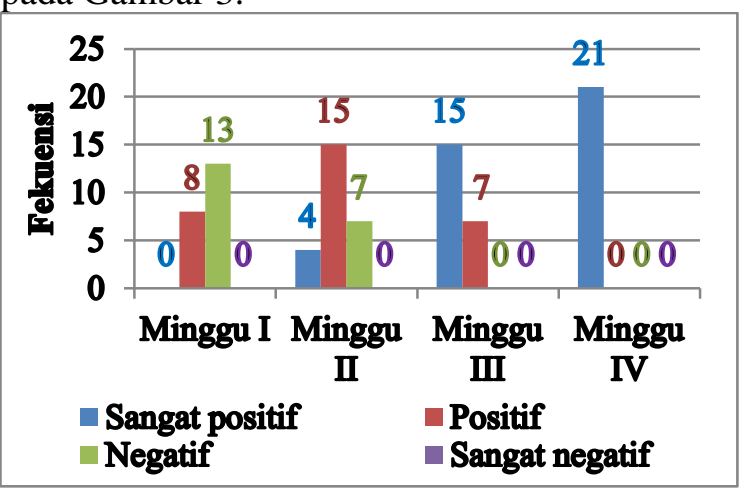

Gambar 3. Histogram Skor HasiL lembar Observasi checklist Karakter Disiplin Peserta Didik $\mathrm{KE}_{1}$

Berdasarkan Gambar 3, diketahui skor aktual yang diperoleh peserta didik berkategori nilai "sangat positif" terjadi peningkatan setiap minggunya, dapat disimpulkan bahwa penggunaan SSP tematik dapat meningkatkan karakter kejujuran peserta didik.

Hasil lembar observasi checklist karakter kejujuran peserta didik $\mathrm{KE}_{2}$ pada empat minggu disajikan pada Tabel 7.

Tabel 7. Hasil lembar Observasi checklist Karakter Kejujuran $\mathrm{KE}_{2}$

\begin{tabular}{ccccc}
\hline \multirow{2}{*}{ Keterangan } & \multicolumn{4}{c}{ Skor tiap minggu } \\
\cline { 2 - 5 } & I & II & III & IV \\
\hline $\mathrm{M}$ & 14.86 & 17.48 & 20.14 & 22.95 \\
$\mathrm{Me}$ & 15.00 & 17.00 & 20.00 & 23.00 \\
$\mathrm{Mo}$ & 15.00 & 16.00 & 18.00 & 23.00 \\
$\mathrm{~s}$ & 1.681 & 1.806 & 2.056 & 1.909 \\
$\mathrm{~s}^{2}$ & 2.829 & 3.262 & 4.229 & 3.648 \\
\hline
\end{tabular}

Berdasarkan pada Tabel 7, terdapat perbedaan skor yang diperoleh peserta didik $\mathrm{KE}_{2}$ setiap minggunya. Hal ini menunjukkan bahwa terdapat peningkatan karakter kejujuran peserta 


\section{Jurnal Prima Edukasia, 5 (1), January 2017 - 84}

M. Masnur

didik $\mathrm{KE}_{2}$ setelah penggunaan SSP. Data skor hasil observasi penilaian karakter kejujuran, kemudian dikelompokkan sesuai kategori nilai yang diperoleh peserta didik. Untuk lebih jelasnya dapat dilihat pada Tabel 4 .

Tabel 8. Skor Hasil lemabr Observasi checklist Karakter Kejujuran Peserta Didik $\mathrm{KE}_{2}$

\begin{tabular}{cccccc}
\hline \multirow{2}{*}{ Kategori } & \multirow{2}{*}{ Skor } & \multicolumn{5}{c}{ Observasi tiap minggu } \\
\cline { 3 - 6 } & & I & II & III & IV \\
\hline $\mathrm{Sp}$ & $\mathrm{X} \geq 21$ & - & 1 & 7 & 19 \\
$\mathrm{P}$ & $21>\mathrm{X} \geq 17,5$ & - & 9 & 12 & 2 \\
$\mathrm{~N}$ & $17,5>\mathrm{X} \geq 14$ & 16 & 11 & 2 & - \\
$\mathrm{Sn}$ & $\mathrm{X}<14$ & 5 & - & - & - \\
Jumlah peserta didik & 21 & 21 & 21 & 21 \\
\hline
\end{tabular}

Data skor aktual yang diperoleh peserta didik setiap minggunya dikelompokkan sesuai kategori nilai yang diperoleh, untuk lebih jelasnya dapat disajikan kedalam histogram seperti pada Gambar 4.

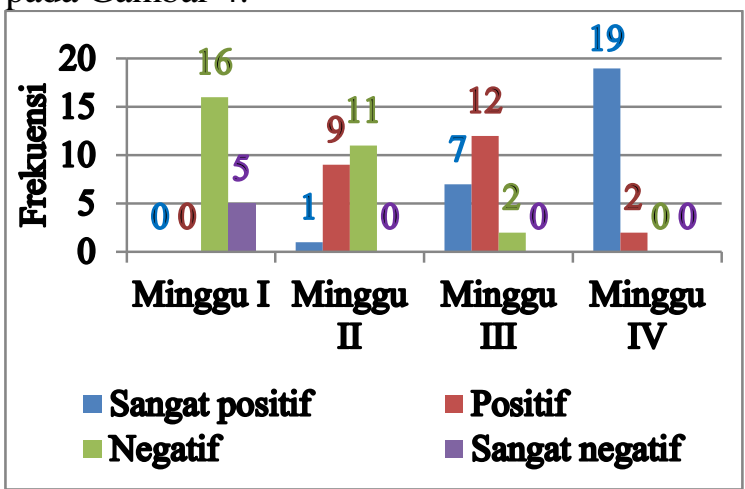

Gambar 4. Histogram Skor Hasil lembar Observasi checklist Karakter Kejujuran Peserta Didik $\mathrm{KE}_{2}$

Berdasarkan Gambar 4, diketahui skor aktual yang diperoleh peserta didik berkategori nilai "sangat positif" terjadi peningkatan setiap minggunya, dapat disimpulkan bahwa penggunaan SSP tematik dapat meningkatkan karakter kejujuran peserta didik.

Hasil observasi karakter disiplin peserta didik $\mathrm{KE}_{2}$ setiap minggunya disajikan pada Tabel 9.

Tabel 9. Hasil Observasi Karakter Disiplin $\mathrm{KE}_{1}$

\begin{tabular}{ccccc}
\hline \multirow{2}{*}{ Keterangan } & \multicolumn{4}{c}{ Skor tiap minggu } \\
\cline { 2 - 5 } & I & II & III & IV \\
\hline$M$ & 17.95 & 20.19 & 22.90 & 26.95 \\
$M e$ & 18.00 & 20.00 & 23.00 & 27.00 \\
$M o$ & 18.00 & 21.00 & 24.00 & 28.00 \\
$s$ & 1.499 & 1.470 & 1.513 & 1.465 \\
$s^{2}$ & 2.248 & 2.162 & 2.290 & 2.148 \\
\hline
\end{tabular}

Berdasarkan pada Tabel 9, terdapat perbedaan skor yang diperoleh peserta didik $\mathrm{KE}_{2}$ setiap minggunya. Hal ini menunjukkan bahwa terdapat peningkatan karakter disiplin peserta didik $\mathrm{KE}_{2}$ setelah penggunaan SSP. Data skor hasil observasi penilaian karakter disiplin, kemudian dikelompokkan sesuai kategori nilai yang diperoleh peserta didik. Untuk lebih jelasnya dapat dilihat pada Tabel 10.

Tabel 10. Skor Hasil lembar Observasi checklist Karakter Disiplin Peserta Didik $\mathrm{KE}_{2}$

\begin{tabular}{cccccc}
\hline \multirow{2}{*}{ Kategori } & \multirow{2}{*}{ Skor } & \multicolumn{5}{c}{ Observasi tiap minggu } \\
\cline { 3 - 6 } & & I & II & III & IV \\
\hline Sp & $\mathrm{X} \geq 24$ & - & - & 9 & 21 \\
$\mathrm{P}$ & $24>\mathrm{X} \geq 20$ & 3 & 15 & 12 & - \\
$\mathrm{N}$ & $20>\mathrm{X} \geq 16$ & 17 & 6 & - & - \\
$\mathrm{Sn}$ & $\mathrm{X}<16$ & 1 & - & - & - \\
Jumlah peserta didik & 21 & 21 & 21 & 21 \\
\hline
\end{tabular}

Data skor aktual yang diperoleh peserta didik setiap minggunya dikelompokkan sesuai kategori nilai yang diperoleh, untuk lebih jelasnya dapat disajikan kedalam histogram seperti pada Gambar 5.

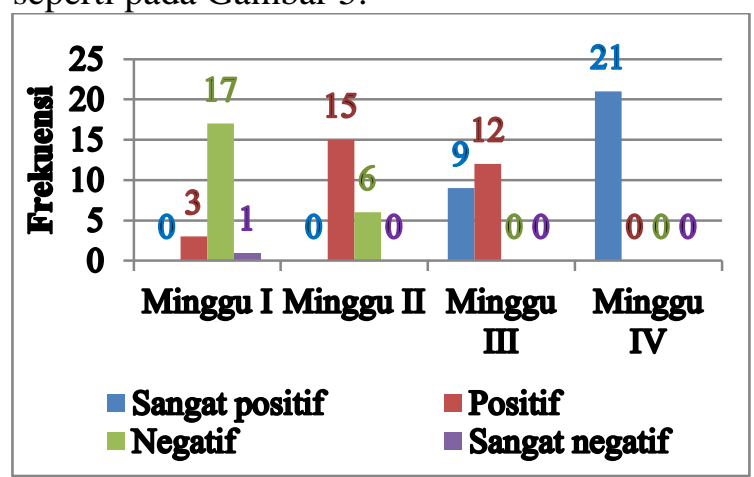

Gambar 5. Histogram Skor Hasil lembar Observasi checklist Karakter Disiplin Peserta Didik $\mathrm{KE}_{2}$

Berdasarkan Gambar 5, diketahui skor aktual yang diperoleh peserta didik berkategori nilai "sangat positif" terjadi peningkatan setiap minggunya, dapat disimpulkan bahwa penggunaan SSP tematik dapat meningkatkan karakter disiplin peserta didik.

Hasil lembar observasi checklist karakter kejujuran peserta didik KK setiap minggunya disajikan pada Tabel 11.

Tabel 11. Hasil lembar Observasi checklist Karakter Kejujuran KK

\begin{tabular}{ccccc}
\hline \multirow{2}{*}{ Keterangan } & \multicolumn{4}{c}{ Skor tiap mingu } \\
\cline { 2 - 5 } & I & II & III & IV \\
\hline$M$ & 12.52 & 13.48 & 15.00 & 16.71 \\
$M e$ & 13.00 & 14.00 & 15.00 & 17.00 \\
$M o$ & 14.00 & 14.00 & 17.00 & 17.00 \\
$s$ & 1.778 & 1.661 & 1.923 & 1.874 \\
$s^{2}$ & 3.162 & 2.762 & 3.700 & 3.514 \\
\hline
\end{tabular}


Berdasarkan pada Tabel 11, terdapat perbedaan skor yang diperoleh peserta didik KK setiap minggunya. Hal ini menunjukkan bahwa terdapat peningkatan karakter kejujuran peserta didik KK setelah penggunaan SSP.

Data skor hasil observasi penilaian karakter kejujuran, kemudian dikelompokkan sesuai kategori nilai yang diperoleh peserta didik. Untuk lebih jelasnya dapat dilihat pada Tabel 12.

Tabel 12. Skor Hasil lembar Observasi checklist karakter Kejujuran Peserta Didik KK

\begin{tabular}{cccccc}
\hline \multirow{2}{*}{ Kategori } & \multirow{2}{*}{ Skor } & \multicolumn{5}{c}{ Observasi tiap minggu } \\
\cline { 3 - 6 } & & I & II & III & IV \\
\hline $\mathrm{Sp}$ & $\mathrm{X} \geq 21$ & - & - & 1 & - \\
$\mathrm{P}$ & $21>\mathrm{X} \geq 17,5$ & - & 13 & 14 & 7 \\
$\mathrm{~N}$ & $17,5>\mathrm{X} \geq 14$ & 8 & 8 & 6 & 14 \\
$\mathrm{Sn}$ & $\mathrm{X}<14$ & 13 & - & - & - \\
Jumlah peserta didik & 21 & 21 & 21 & 21 \\
\hline
\end{tabular}

Data skor aktual yang diperoleh peserta didik setiap minggunya dikelompokkan sesuai kategori nilai yang diperoleh, untuk lebih jelasnya dapat disajikan kedalam histogram seperti pada Gambar 6.

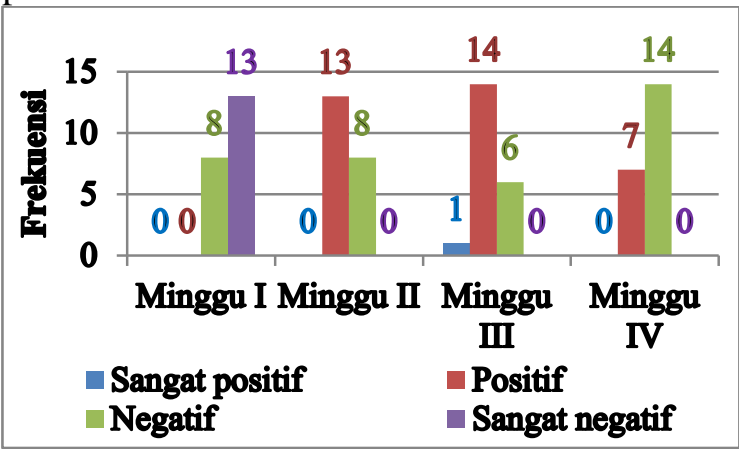

Gambar 6. Histogram Skor Hasil Observasi

Karakter Kejujuran Peserta Didik KK

Berdasarkan Gambar 6, diketahui skor aktual yang diperoleh peserta didik berkategori nilai "positif" terjadi peningkatan setiap minggunya, dapat disimpulkan bahwa pembelajaran tematik yang tidak menggunakan SSP tematik dapat meningkatkan karakter kejujuran peserta didik.

Hasil lembar observasi checklist karakter disiplin peserta didik KK setiap minggunya disajikan pada Tabel 13 .

Berdasarkan pada tabel 13, terdapat perbedaan skor yang diperoleh peserta didik KK setiap minggunya. Hal ini menunjukkan bahwa terdapat peningkatan karakter disiplin peserta didik KK setelah penggunaan SSP. Data skor hasil observasi penilaian karakter disiplin, kemudian dikelompokkan sesuai kategori nilai yang diperoleh peserta didik. Untuk lebih jelasnya dapat dilihat pada Tabel 14 .

Tabel 13. Hasil lembar Observasi checklist Karakter Disiplin KK

\begin{tabular}{ccccc}
\hline \multirow{2}{*}{ Keterangan } & \multicolumn{4}{c}{ Skor tiap minggu } \\
\cline { 2 - 5 } & I & II & III & IV \\
\hline$M$ & 16.00 & 17.00 & 17.95 & 18.86 \\
$M e$ & 16.00 & 17.00 & 18.00 & 19.00 \\
$M o$ & 16.00 & 19.00 & 20.00 & 21.00 \\
$s$ & 2.236 & 2.191 & 2.268 & 1.957 \\
$s^{2}$ & 5.000 & 4.800 & 5.148 & 3.829 \\
\hline
\end{tabular}

Tabel 14. Skor Hasil lembar Observasi checklist Karakter Disiplin Peserta Didik KK

\begin{tabular}{cccccc}
\hline \multirow{2}{*}{ Kategori } & \multirow{2}{*}{ Skor } & \multicolumn{5}{c}{ Observasi tiap minggu } \\
\cline { 3 - 6 } & & I & II & III & IV \\
\hline Sp & $\mathrm{X} \geq 24$ & - & - & & \\
$\mathrm{P}$ & $24>\mathrm{X} \geq 20$ & - & 2 & 8 & 9 \\
$\mathrm{~N}$ & $20>\mathrm{X} \geq 16$ & 14 & 12 & 8 & 12 \\
$\mathrm{Sn}$ & $\mathrm{X}<16$ & 7 & 7 & 5 & - \\
Jumlah peserta didik & 21 & 21 & 21 & 21 \\
\hline
\end{tabular}

Data skor aktual yang diperoleh peserta didik setiap minggunya dikelompokkan sesuai kategori nilai yang diperoleh, untuk lebih jelasnya dapat disajikan kedalam histogram seperti pada Gambar 7.

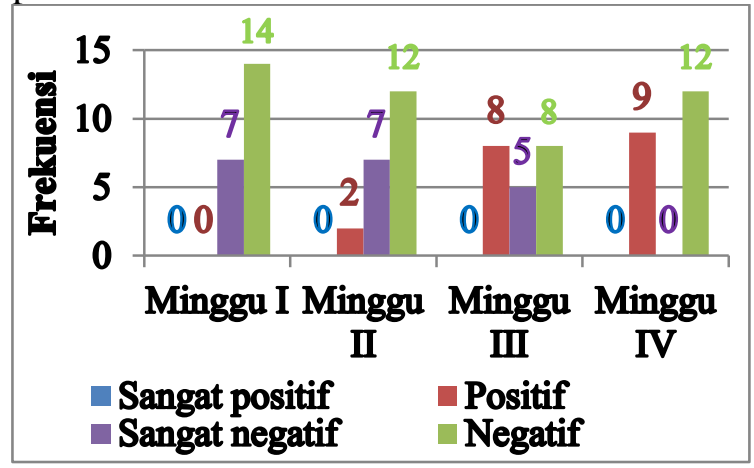

Gambar 7. Histogram Skor Hasil lembar Observasi checklist Karakter Disiplin Peserta Didik KK

Berdasarkan Gambar 7, diketahui skor aktual yang diperoleh peserta didik berkategori nilai "positif" terjadi peningkatan setiap minggunya, dapat disimpulkan bahwa pembelajaran tematik yang tidak menggunakan SSP tematik dapat meningkatkan karakter disiplin peserta didik.

Hasil angket karakter kejujuran peserta didik $\mathrm{KE}_{1}$ berupa skor pretest dan posttest, kemudian dikelompokkan sesuai kategori nilai yang diperoleh peserta didik. Secara singkat dapat dideskripsikan data nilai karakter yang mengungkapkan informasi yaitu: Sangat positif $(\mathrm{Sp})$, Positif (P), Negatif (N), dan Sangat nega- 
tif (Sn), untuk lebih jelasnya dapat dilihat pada Tabel 15.

Tabel 15. Skor Pretest-dan Posttest Karakter Kejujuran $\mathrm{KE}_{1}$

\begin{tabular}{cccc}
\hline Kategori & Skor & Pretest & Posttest \\
\hline Sp & $\mathrm{X} \geq 30$ & - & 16 \\
$\mathrm{P}$ & $30>\mathrm{X} \geq 25$ & 11 & 5 \\
$\mathrm{~N}$ & $25>\mathrm{X} \geq 20$ & 9 & - \\
Sn & $\mathrm{X}<20$ & 1 & - \\
& Jumlah & 21 & 21 \\
\hline
\end{tabular}

Berdasarkan Tabel 15, diperoleh skor pretest peserta didik berkategori "sangat positif" mengalami peningkatan pada skor posttest sebanyak 16 peserta didik, dapat disimpulkan bahwa penggunaan SSP tematik dapat meningkatkan karakter kejujuran peserta didik.

Hasil angket karakter disiplin peserta didik $\mathrm{KE}_{1}$ berupa skor pretest dan posttest, kemudian dikelompokkan sesuai kategori nilai yang diperoleh peserta didik. Secara singkat dapat dideskripsikan data nilai karakter yang mengungkapkan informasi yaitu: Sangat positif (Sp), Positif (P), Negatif (N), dan Sangat negatif $(\mathrm{Sn})$, untuk lebih jelasnya dapat dilihat pada Tabel 16.

Tabel 16. Skor Pretest dan Posttest Karakter Disiplin $\mathrm{KE}_{1}$

\begin{tabular}{cccc}
\hline Kategori & Skor & Pretest & Posttest \\
\hline $\mathrm{Sp}$ & $\mathrm{X} \geq 30$ & - & 20 \\
$\mathrm{P}$ & $30>\mathrm{X} \geq 25$ & 12 & 1 \\
$\mathrm{~N}$ & $25>\mathrm{X} \geq 20$ & 9 & - \\
$\mathrm{Sn}$ & $\mathrm{X}<20$ & 1 & - \\
\multicolumn{2}{c}{ Jumlah } & 21 & 21 \\
\hline
\end{tabular}

Berdasarkan Tabel 16, diperoleh skor pretest peserta didik berkategori "sangat positif" mengalami peningkatan pada skor posttest sebanyak 20 peserta didik, dapat disimpulkan bahwa penggunaan SSP tematik dapat meningkatkan karakter disiplin peserta didik.

Angket Penilaian Karakter Kejujuran $\mathrm{KE}_{2}$

Hasil angket karakter kejujuran peserta didik $\mathrm{KE}_{2}$ berupa skor pretest dan posttest, kemudian dikelompokkan sesuai kategori nilai yang diperoleh peserta didik. Secara singkat dapat dideskripsikan data nilai karakter yang mengungkapkan informasi yaitu: Sangat positif $(\mathrm{Sp})$, Positif (P), Negatif (N), dan Sangat negatif (Sn), untuk lebih jelasnya dapat dilihat pada Tabel 17.
Tabel 17. Skor Pretest dan Posttest Karakter Kejujuran $\mathrm{KE}_{2}$

\begin{tabular}{cccc}
\hline Kategori & Skor & Pretest & Posttest \\
\hline Sp & $\mathrm{X} \geq 30$ & - & 19 \\
$\mathrm{P}$ & $30>\mathrm{X} \geq 25$ & 13 & 5 \\
$\mathrm{~N}$ & $25>\mathrm{X} \geq 20$ & 7 & - \\
$\mathrm{Sn}$ & $\mathrm{X}<20$ & 1 & - \\
\multicolumn{2}{c}{ Jumlah } & 21 & 21 \\
\hline \multicolumn{2}{c}{ Berdasarkan Tabel 17, diperoleh skor }
\end{tabular}
pretest peserta didik berkategori "sangat positif" mengalami peningkatan pada skor posttest sebanyak 19 peserta didik, dapat disimpulkan bahwa penggunaan SSP tematik dapat meningkatkan karakter kejujuran peserta didik.

Hasil angket karakter disiplin peserta didik $\mathrm{KE}_{2}$ berupa skor pretest dan posttest, kemudian dikelompokkan sesuai kategori nilai yang diperoleh peserta didik. Secara singkat dapat dideskripsikan data nilai karakter yang mengungkapkan informasi yaitu: Sangat positif (Sp), Positif (P), Negatif $(\mathrm{N})$, dan Sangat negatif (Sn), untuk lebih jelasnya dapat dilihat pada Tabel 18.

Tabel 18. Skor Pretest dan Posttest Karakter Disiplin $\mathrm{KE}_{2}$

\begin{tabular}{cccc}
\hline Kategori & Skor & Pretest & Posttest \\
\hline $\mathrm{Sp}$ & $\mathrm{X} \geq 30$ & - & 19 \\
$\mathrm{P}$ & $30>\mathrm{X} \geq 25$ & 14 & 1 \\
$\mathrm{~N}$ & $25>\mathrm{X} \geq 20$ & 7 & 1 \\
$\mathrm{Sn}$ & $\mathrm{X}<20$ & - & - \\
\multicolumn{2}{c}{ Jumlah } & 21 & 21 \\
\hline
\end{tabular}

Berdasarkan Tabel 18, diperoleh skor pretest peserta didik berkategori "sangat positif" mengalami peningkatan pada skor posttest sebanyak 19 peserta didik, dapat disimpulkan bahwa penggunaan SSP tematik dapat meningkatkan karakter disiplin peserta didik.

Hasil angket karakter kejujuran peserta didik KK berupa skor pretest dan posttest, kemudian dikelompokkan sesuai kategori nilai yang diperoleh peserta didik. Secara singkat dapat dideskripsikan data nilai karakter yang mengungkapkan informasi yaitu: Sangat positif $(\mathrm{Sp})$, Positif (P), Negatif (N), dan Sangat negatif (Sn). Data dapat dilihat pada Tabel 19.

Tabel 19. Skor Pretest dan Posttest Karakter Kejujuran KK

\begin{tabular}{cccc}
\hline Kategori & Skor & Pretest & Posttest \\
\hline Sp & $\mathrm{X} \geq 30$ & - & 2 \\
$\mathrm{P}$ & $30>\mathrm{X} \geq 25$ & 13 & 19 \\
$\mathrm{~N}$ & $25>\mathrm{X} \geq 20$ & 7 & - \\
Sn & $\mathrm{X}<20$ & 1 & - \\
\multicolumn{2}{c}{ Jumlah } & 21 & 21 \\
\hline
\end{tabular}


Berdasarkan Tabel 19, diperoleh skor pretest peserta didik berkategori "sangat positif" mengalami peningkatan pada skor posttest sebanyak 2 peserta didik, dapat disimpulkan bahwa pembelajaran tematik yang tidak menggunakan SSP tematik dapat meningkatkan karakter kejujuran peserta didik.

Hasil angket karakter disiplin peserta didik KK berupa skor pretest dan posttest, kemudian dikelompokkan sesuai kategori nilai yang diperoleh peserta didik. Secara singkat dapat dideskripsikan data nilai karakter yang mengungkapkan informasi yaitu: Sangat positif $(\mathrm{Sp})$, Positif (P), Negatif (N), dan Sangat negatif $(\mathrm{Sn})$, untuk lebih jelasnya dapat dilihat pada Tabel 20

Tabel 20. Skor Pretest dan Posttest Karakter Disiplin KK

\begin{tabular}{cccc}
\hline Kategori & Skor & Pretest & Posttest \\
\hline Sp & $\mathrm{X} \geq 30$ & - & 11 \\
$\mathrm{P}$ & $30>\mathrm{X} \geq 25$ & 11 & 10 \\
$\mathrm{~N}$ & $25>\mathrm{X} \geq 20$ & 10 & - \\
$\mathrm{Sn}$ & $\mathrm{X}<20$ & 1 & - \\
& Jumlah & 21 & 21 \\
\hline
\end{tabular}

Berdasarkan Tabel 20, diperoleh skor pretest peserta didik berkategori "sangat positif" mengalami peningkatan pada skor posttest sebanyak 11 peserta didik. dapat disimpulkan bahwa penggunaan SSP tematik dapat meningkatkan karakter disiplin peserta didik. Selanjutnya, data yang diperoleh dianalisis dengan ANOVA. Namun, sebelumnya perlu diuji prasyarat analisis dengan ujii normalitas dan homogenitas.

Berdasarkan hasil perhitungan uji normalitas dengan kolmogrov-sminov dengan bantuan komputer menggunakan program SPSS 20.00 for windows. Kolmogorov-Smirnov, diperoleh bahwa data kelompok eksperimen dan kelompok kontrol berdistribusi normal.

Selanjutnya dilakukan Uji homogenitas terhadap varians antar kelompok eksperimen dan kontrol. Uji yang digunakan adalah levene'stest for equality variansces dengan ban- tuan computer dengan menggunakan program SPSS 20.00 for windows. Berdasarkan perhitungan yang dilakukan diperoleh bahwa varians data angket karakter peserta diidk kelompok eksperimen dan kontrol adalah homogen.

Setelah diperoleh hasil dari uji prasyarat analisis data, dilanjutkan dengan ANOVA dengan bantuan komputer menggunakan program SPSS 20.00 for windows. Hasil ANOVA antara kelompok eksperimen dan kontrol disajikan pada Tabel 21.

Data yang diperoleh dianalisis dengan ANOVA. Berdasarkan hasil analisis Hasil ANOVA pada karakter kejujuran diperoleh nilai $\mathrm{F}=27,890$ dengan $\mathrm{p}$ value $=0,000 . \mathrm{H}_{0}$ pada uji ANOVA adalah tidak ada perbedaan nilai rata-rata karakter kejujuran antara $\mathrm{KE}_{1}$, $\mathrm{KE}_{2}$, dan KK. Sedangkan $\mathrm{H}_{1}$ adalah terdapat perbedaan nilai rata-rata karakter kejujuran antara $\mathrm{KE}_{1}, \mathrm{KE}_{2}$, dan $\mathrm{KK}$. Berdasarkan hasil ANOVA dapat disimpulkan bahwa taraf signifikansi hasil hitung sebesar $p=0,000<0,05=$ $\alpha$, sehingga $\mathrm{H}_{0}$ di tolak dan $\mathrm{H}_{1}$ diterima. Dengan demikian terdapat perbedaan pengaruh yang signifikan antara penggunaan SSP menggunakan SSP tematik terhadap karakter kejujuran peserta didik kelas 1 SDN di Kecamatan Ujung Kota Parepare.

Hasil ANOVA pada karakter disiplin diperoleh nilai $\mathrm{F}=9,294$ dengan $\mathrm{p}$ value $=0$, 000. $\mathrm{H}_{0}$ pada uji ANOVA adalah tidak ada perbedaan nilai rata-rata karakter kejujuran antara $\mathrm{KE}_{1}, \mathrm{KE}_{2}$, dan KK. Sedangkan $\mathrm{H}_{1}$ adalah terdapat perbedaan nilai rata-rata karakter disiplin antara $\mathrm{KE}_{1}, \mathrm{KE}_{2}$, dan $\mathrm{KK}$. Berdasarkan hasil ANOVA dapat disimpulkan bahwa taraf signifikansi hasil hitung sebesar $p=0,000<0,05=$ $\alpha$, sehingga $\mathrm{H}_{0}$ di tolak dan $\mathrm{H}_{1}$ diterima. Dengan demikian terdapat perbedaan pengaruh yang signifikan antara penggunaan SSP tematik dan pembelajaran tematik yang tidak menggunakan SSP tematik terhadap karakter disiplin peserta didik kelas 1 SDN di Kecamatan Ujung Kota Parepare.

Tabel 21. Hasil Uji ANAVA

\begin{tabular}{llccccc}
\hline & & Sum of Squares & df & Mean Square & F & Sig. \\
\hline Karakter Kejujuran & Between Groups & 260.571 & 2 & 130.286 & 27.890 & .000 \\
& Within Groups & 280.286 & 60 & 4.671 & & \\
& Total & 540.857 & 62 & & & \\
Karakter Disiplin & Between Groups & 183.746 & 2 & 91.873 & 9.294 & .000 \\
& Within Groups & 593.143 & 60 & 9.886 & & \\
& Total & 776.889 & 62 & & & \\
\hline
\end{tabular}


Untuk mengetahui adanya pengaruh SSP tematik terhadap peningkatan karakter kejujuran peserta didik, dapat dengan membandingkan nilai rata-rata karakter yang diperoleh antara ketiga kelompok sampel. untuk lebih jelasnya dapat dilihat Tabel 22.

Tabel 22. Nilai rata-rata Hasil lembar Observasi checklist Karakter Kejujuran Peserta Didik Tiap Minggu

\begin{tabular}{ccccc}
\hline \multirow{2}{*}{ Kelompok } & \multicolumn{4}{c}{ Skor tiap minggu } \\
\cline { 2 - 5 } & I & II & III & IV \\
\hline $\mathrm{KE}_{1}$ & 14.61 & 16.62 & 19.28 & 22.86 \\
$\mathrm{KE}_{2}$ & 14.86 & 17.48 & 20.14 & 22.95 \\
$\mathrm{KK}$ & 12.52 & 13.48 & 15 & 16.71 \\
\hline
\end{tabular}

Berdasarkan pada Tabel 22, terdapat perbedaan mean karakter kejujuran peserta didik $\mathrm{KE}_{1}, \mathrm{KE}_{2}$, dan $\mathrm{KK}$. Hal ini menunjukkan bahwa terdapat peningkatan karakter kejujuran peserta didik pada $\mathrm{KE}_{1}, \mathrm{KE}_{2}$ setelah penggunaan SSP tematik. Untuk mengetahui lebih jelasnya dapat dideskripsikan hasil observasi karakter kejujuran pada setiap minggunya kedalam bentuk poligon seperti yang disajikan pada Gambar 8.



Gambar 8. Poligon Peningkatan Nilai Rata-Rata Hasil lembar Observasi checklist Karakter Kejujuran Tiap Minggunya

Berdasarkan Gambar 8, menunjukkan bahwa terdapat peningkatan yang signifikan terhadap nilai karakter kejujuran peserta didik pada pembelajaran tematik kelas I SDN di Kecamatan Ujung Kota Parepare. Hasil penelitian menunjukkan bahwa ketika guru sering mengaitkan materi pembelajaran dengan menanamkan nilai kejujuran, maka peserta didik akan mengetahui bahwa bersikap tidak jujur dapat merugikan dirinya sendiri maupun orang lain.

Penggunaan SPP tematik dikelas eksperimen berpengaruh positif terhadap peningkatan karakter disiplin peserta didik, hal ini tercermin dari aktivitas peserta didik selama pembelajaran berlangsung seperti: peserta didik mampu menceritakan alasan yang sesungguhnya ketika datang terlambat, meminta maaf jika melakukan kesalahan, tidak menyalahkan teman atas kesalahannya, mengembalikan barang temannya yang sudah dipinjam, mengumunkan bila menemukan sesuatu/barang di kelas dan menyerahkan kepada guru, tidak menyontek pekerjaan/ tugas teman sekelas, dan meminta izin bila akan memakai barang milik temannya.

Untuk mengetahui adanya pengaruh SSP tematik terhadap peningkatan karakter disiplin peserta didik, dapat dengan membandingkan nilai rata-rata karakter yang diperoleh antara ketiga kelompok sampel. untuk lebih jelasnya dapat dilihat Tabel 23.

Tabel 23. Nilai rata-rata Hasil lembar Observasi checklist Karakter Disiplin Peserta Didik Tiap Minggu

\begin{tabular}{ccccc}
\hline \multirow{2}{*}{ Kelompok } & \multicolumn{4}{c}{ Skor tiap minggu } \\
\cline { 2 - 5 } & I & II & III & IV \\
\hline $\mathrm{KE}_{1}$ & 18.67 & 21.67 & 24.23 & 26.95 \\
$\mathrm{KE}_{2}$ & 17.95 & 20.19 & 22.9 & 26.95 \\
$\mathrm{KK}$ & 16 & 17 & 17.95 & 18.86 \\
\hline
\end{tabular}

Berdasarkan Tabel 23, terdapat perbedaan mean karakter disiplin peserta didik $\mathrm{KE}_{1}$, $\mathrm{KE}_{2}$, dan KK. Hal ini menunjukkan bahwa terdapat peningkatan karakter disiplin peserta didik pada $\mathrm{KE}_{1}, \mathrm{KE}_{2}$ setelah penggunaan SSP tematik. Untuk mengetahui lebih jelasnya dapat dideskripsikan hasil lembar observasi checklist karakter kejujuran pada setiap minggunya ke dalam bentuk poligon seperti yang disajikan pada Gambar 9.

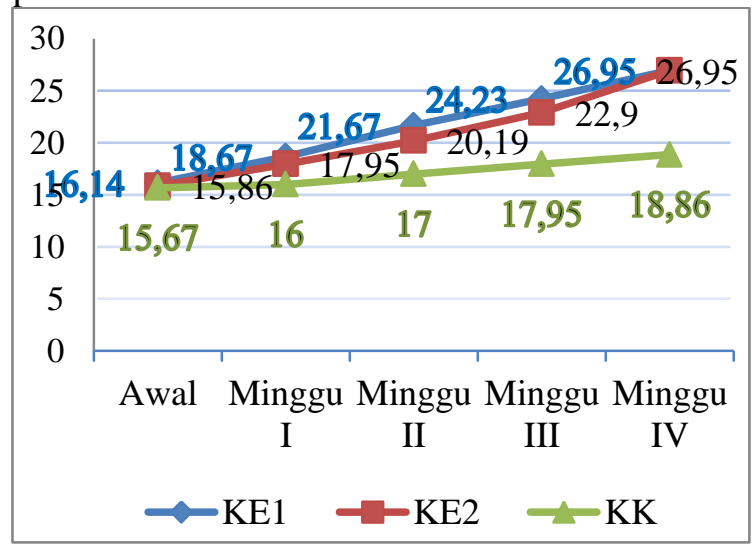

Gambar 9. Poligon Peningkatan Nilai Rata-Rata Hasil lembar Observasi checklist Karakter Disiplin Tiap Minggunya

Berdasarkan Gambar 9, menunjukkan bahwa terdapat peningkatan yang signifikan 
terhadap nilai karakter disiplin peserta didik pada pembelajaran tematik kelas I SDN di Kecamatan Ujung Kota Parepare. Hasil penelitian menunjukkan bahwa ketika guru sering mengaitkan materi pembelajaran dengan menanamkan nilai disiplin, maka peserta didik akan mengetahui bahwa prilaku tidak disiplin dapat merugikan dirinya sendiri maupun orang lain.

Penggunaan SPP tematk dikelas eksperimen berpengaruh positif terhadap peningkatan karakter disiplin peserta didik, hal ini tercermin dari aktivitas peserta didik selama pembelajaran berlangsung seperti: peserta didik datang ke sekolah tepat waktu, memakai seragam sekolah dengan rapi dan sesuai jadwalnya, mengekspresikan keinginannya pada tempat yang sudah disediakan (untuk corat-coret, menyanyi, drama, dan sebagainya), mengembalikan alat/ bahan setelah selesai digunakan, meminta tambahan waktu untuk mengerjakan tugas di kelas, mendengarkan penjelasan guru pada saat pelajaran berlangsung, mengumpulkan tugas tepat waktu, dan mengumpulkan tugas tepat waktu.

Secara teoretik, temuan yang menunjukkan bahwa Subject Specific Pedagogy (SSP) atau Pedagogy content knowledge (PCK) berpengaruh positif terhadap nilai karakter peserta didik. Menurut Schmid.D.A., et al. (2009, p.125) bahwa "Pedagogy content knowledge is different for various content areas, as it blends both content and pedagogy with the goal being to develop better teaching practices in the content areas." Dari pernyataan tersebut bahwa PCK merupakan perangkat pembelajaran yang mencakup beberapa unsur-unsur penting yang mencakup pengetahuan tentang mata pelajaran yang akan diajarkan, pengetahuan tentang karakteristik dan perkembangan peserta didik sehingga tidak terjadi kesalahpahaman dalam proses pembelajaran, pengetahuan tentang komponen-komponen kurikulum, dan pengetahuan tentang konsep pedagogi yang diasumsikan sebagai cara atau metode yang digunakan oleh guru dalam mendidik untuk meningkatkan pembelajaran.

Pembelajaran dengan menggunakan SPP memandu pikiran peserta didik tentang pentingnya memiliki nilai karakter kejujuran dan disiplin. Hal ini sesuai dengan temuan dari penelitian (Paimun \& Masruri, 2014). Dalam melakukan penelitian pengembangan (R\&D) dengan judul Pengembangan SSP untuk meningkatkan karakter kejujuran dan disiplin peserta didik memberikan pengaruh positif bagi pembelajaran, sehingga terjadi peningkatan nilai karakter peserta didik. sejalan dengan hasil penelitian yang telah disebutkan di atas, sudah sesuai dengan unsur-unsur dalam perangkat pembelajaran berupa SSP yaitu: (1) mampu menanamkan dan meningkatkan nilai karakter, (2) mampu mengklarifikasi/menggali dan mengungkapkan isi pesan materi yang disampaikan selanjutnya akan memudahkan guru untuk menyampaikan makna/pesan/nilai/moral, (3) mampu mengintegrasikan pendidikan karakter ke dalam pembelajaran tematik, (4) memberikan gambaran nilai karakter kejujuran dan displin yang patut diterima dan menuntun serta memotivasi untuk hidup layak dan berkarakter positif.

Berbeda halnya dalam pembelajaran tematik yang tidak menggunakan SSP tematik membuat peserta didik lebih banyak mendengar ceramah, sehingga cenderung pasif. Dalam pembelajaran ini, guru lebih banyak mendominasi kegiatan pembelajaran. Penanaman nilai karakter dilakukan dengan ceramah yang cenderung membuat peserta didik tegang dan sulit memahami apa makna dari nilai karakter itu. Selain itu, peserta didik lebih banyak memfokuskan pada buku pegangan siswa yang mengakibatkan kurang memahami secara mendalam substansi materinya.

Perbedaan cara pembelajaran antara penggunaan SSP tematik dan pembelajaran tematik yang tidak menggunakan SSP tematik tentunya akan memberikan dampak yang berbeda pula peningkatan nilai karakter kejujuran dan disiplin peserta didik. Pembelajaran dengan menggunakan SSP tematik memberikan pengalaman langsung kepada peserta didik terhadap nilai-nilai karakter bahkan sudah sering dilakukan dalam kehidupan sehri-hari serta dirancang lebih menyenangkan, sehingga peningkatan karakter kejujuran dan disiplin peserta didik dengan menggunakan SSP tematik akan lebih baik dibandingkan pembelajaran tematik yang tidak menggunakan SSP tematik.

\section{Simpulan}

Berdasarkan hasil penelitian dan hasil analisis data yang telah dilakukan, dapat disimpulkan bahwa: (1) Terdapat perbedaan pengaruh yang signifikan antara penggunaan SSP tematik dan pembelajaran tematik yang tidak menggunakan SSP tematik terhadap karakter kejujuran peserta didik kelas 1 SDN di Kecamatan Ujung Kota Parepare, dan (2) Terdapat perbedaan pengaruh yang signifikan antara 


\section{Jurnal Prima Edukasia, 5 (1), January 2017 - 90}

M. Masnur

penggunaan SSP tematik dan pembelajaran tematik yang tidak menggunakan SSP tematik terhadap karakter disiplin peserta didik kelas 1 SDN di Kecamatan Ujung Kota Parepare

Berdasarkan hasil penelitian maka kepada para guru atau tenaga pengajar di sekolah, diberikan saran-saran sebagai berikut: (1) Perangkat pembelajaran SSP tematik memiliki pengaruh yang lebih baik terhadap katakter kejujuran dan disiplin, sehingga para guru atau tenaga pendidik sebaiknya memilih perangkat pembelajaran yang tersusun dalam SSP tematik, (2) Perangkat pembelajaran SSP tematik perlu memperhatikan komponen-komponen yang termuat dalam SSP tersebut yaitu silabus, RPP, LKS dan lembar penilaian dalam meningkatkan karater kejujuran dan disiplin, (3) Upaya meningkatkan karakter kejujuran dan disiplin akan lebih tepat dan efektif dengan menggunakan perangkat pembelajaran yang mendidik berupa SSP tematik, dan (4) Upaya memaksimalkan pengamatan karakter peserta didik akan lebih efektif dengan menambahkan staf pembantu untuk setiap kelas, guna membantu guru dalam melakukan penilaian.

\section{Daftar Pustaka}

Berk, L. E. (2007). Development through the lifespan. Boston: Pearson Allyn and Bacon.
California State University Northridge. (2006). Effective teaching. Teachers for a New Era. [Online]. Available: http://www.csun.edu/tne/effective\%20tea ching\%20jan\%2006\%20FINAL.pdf. Diakses pada tanggal 27 juni 2014.

Kemendikbud. (2013a). Permendikbud RI No. 70 Tahun 2013. Kerangka dasar dan struktur kurikulum sekolah menengah kejuruan/madrasah aliyah kejuruan.

Lickona, T. (1991). Educating for character: how our schools can teach respect and responsibility. Nuw York: Bantam.

Paimun, P., \& Masruri, M. S. (2014). Pengembangan subject spesific pedagogy tematik untuk meningkatkan kejujuran dan kedisiplinan siswa kelas I SD. Jurnal Prima Edukasia, 2(2), 194-208. http://doi.org/10.21831/jpe.v2i2.2719

Republik Indonesia. (2003). Undang-Undang RI 20 Tahun 2003, Tentang Sistem Pendidikan Nasional.

Mardapi, D. (2008). Teknik penyusunan instrumen tes dan nontes. Yogyakarta: Mitra Cendikia Press.

McMillan, J.H., \& Schumacher, S. (2010). Research in education: Evidence-based inquiry. $7^{\text {th }}$ ed. New York: Pearson Education. Inc. 